\title{
Pelatihan Pembuatan Media Pembelajaran Sempoa Berbasis Teknologi Informasi
}

\author{
Febrina Sari*1, Mustazihim Suhaidi ${ }^{2}$, Wetri Febrina ${ }^{3}$, Desyanti $^{4}$ \\ 1,2Program Studi Teknik Informatika, Sekolah Tinggi Teknologi (STT) Dumai \\ ${ }^{3}$ Program Studi Teknik Industri, Sekolah Tinggi Teknologi (STT) Dumai \\ *e-mail: febri_ghaniya@yahoo.co.id, muja.1708@gmail.com, wetri.febrina@gmail.com, \\ desyanti734@gmail.com
}

\begin{abstract}
Counting is part of the mathematical ability. Based on the results of observations, students' numeracy skills are very low, this can be seen from the low average score for mathematics subjects, especially numeracy. The low numeracy skills of students are caused by teachers who still use conventional methods or lectures in delivering material, Teachers have not been maximized in utilizing learning media, therefore the need for an interactive learning media for mathematics teachers based on information technology in delivering material. The method used to solve the problem is by conducting training in making interactive learning media based on information technology, the results of the implementation of this interactive learning media are students become enthusiastic about learning mathematics and student scores show increase, no longer found students who have scores below the Minimum Completeness Criteria.
\end{abstract}

Keywords: Mathematics, Learning Media, Abacus, Information Technology

\begin{abstract}
Abstrak
Berhitung merupakan bagian dari kemampuan metematika. Berdasarkan hasil observasi kemampuan berhitung siswa sangat rendah hal ini dilihat dari rendahnya perolehan nilai ratarata untuk mata pelajaran matematika khususnya materi berhitung. Rendahnya kemampuan berhitung siswa disebabkan oleh guru yang masih menggunakan metode konvensional atau ceramah dalam penyampaian materi. Guru belum maksimal dalam memanfaatkan media pembelajaran, oleh karena itu perlunya sebuah media pembelajaran interaktif bagi guru matematika berbasis teknologi informasi dalam menyampaikan materi. Metode yang digunakan untuk menyelesaaikan permasalahan yakni dengan mengadakan pelatihan pembuatan media pembelajaran yang interaktif berbasis teknologi informasi, hasil dari implementasi media pembelajaran interaktif ini siswa jadi bersemangat belajar matematika dan nilai rata-rata siswa menunjukkan peningkatan dan tidak lagi ditemukan siswa yang memiliki nilai dibawah Kriteria Ketuntasan Minimal (KKM).
\end{abstract}

Kata kunci: Matematika, Media Pembelajaran, Sempoa, Teknologi Informasi

\section{PENDAHULUAN}

Sekolah Dasar Islam Terpadu Al Izzah Dumai, merupakan lembaga pendidikan dibawah naungan Dinas Pendidikan Kota Dumai, yang beralamat di Jl. Akasia BTN Panorama, Jaya Mukti, Kec. Dumai Timur Kota Dumai. Matematika merupakan salah satu mata pelajaran yang diajarkan di tingkat sekolah dasar, Namun pada kenyataanya matematika masih dianggap pelajaran yang sulit dan sukar dipahami oleh sebagaian peserta didik (Dianto et al., 2018). Pada kelas 1 sekolah dasar merupakan proses awal siswa mengenal operasi hitung, berhitung merupakan bagian dari kemampuan metematika. Kegiatan berhitung dalam konteks yang sederhana telah dikenalkan sebelum siswa memasuki usia sekolah dasar. Banyak siswa mengalami kesulitan dalam belajar matematika karana matematika memiliki sifat yang abstrak, hal ini terlihat dari rendahnya kemampuan berhitung siswa, perolehan nilai rata-rata untuk mata pelajaran matematika khususnya materi berhitung pada siswa kelas 1 SD IT Al Izzah Dumai yaitu 48,25 sedangkan Kriteria Ketuntasan Minimal (KKM) yang ditetapkan adalah 55 .

Berdasarkan analisis situasi dan survey serta wawancara tim pengusul dengan guru dan siswa kelas 1 SDIT Al Izzah Dumai, Rendahnya kemampuan berhitung siswa 
dikarenakan Selama ini dalam penyampaian materi pelajaran berhitung guru masih menggunakan metode konvensional berupa ceramah, cara guru mengajar yang masih monoton dan tidak menarik, guru masih menggunakan media pembelajaran seperti buku paket dan papan tulis dalam menyampaikan materi. Hal ini dapat dilihat pada gambar berikut.
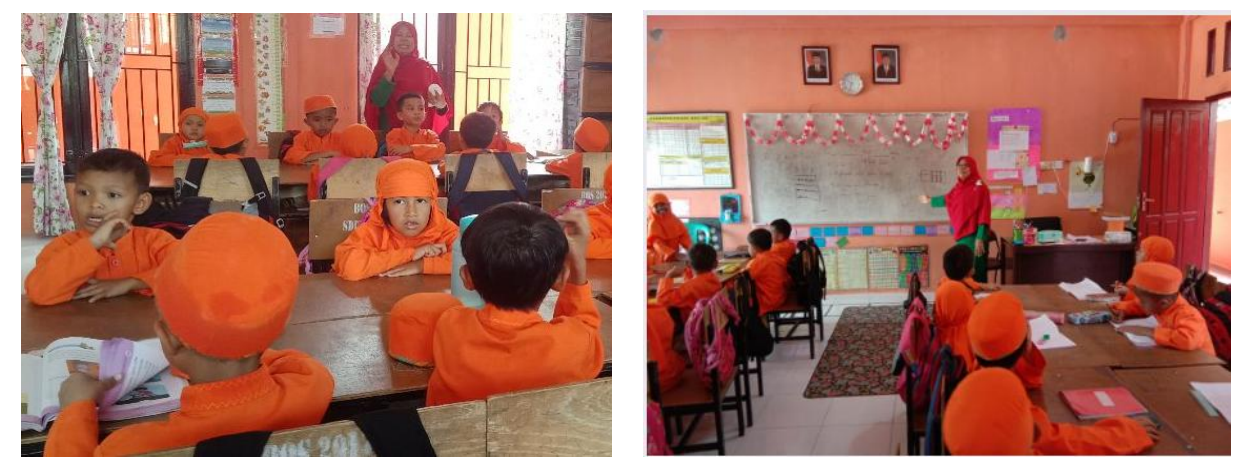

Gambar 1. Guru menyampaikan materi dengan metode ceramah

Pembelajaran merupakan proses komunikasi. Menurut (Ayuningtyas et al., 2018) mengemukakan dalam suatu proses komunikasi selalu melibatkan tiga komponen pokok yaitu komponen pengirim pesan (guru), komponen penerima pesan (murid), dan komponen pesan itu sendiri yang biasanya berupa materi pelajaran. Kadang dalam proses pembelajaran terjadi kegagalan komunikasi. Artinya, materi pelajaran atau pesan yang disampaikan guru tidak dapat diterima oleh murid dengan optimal, artinya tidak seluruh materi pelajaran dapat dipahami dengan baik oleh murid, maka guru perlu mempunyai strategi pembelajaran matematika yang lebih menarik dan menyenangkan dengan penggunaan metode pembelajaran yang lebih bervariatif, metode pembelajaran memegang peran sangat penting dalam penyampaian materi seperti yang disampaikan oleh (Rustyaning \& Arthana, 2016). guru harus bisa memanfaatkan berbagai media dan sumber belajar. Media pembelajaran adalah segala sesuatu yang dapat digunakan untuk menyalurkan pesan dari pengirim ke penerima sehingga dapat merangsang fikiran, perasaan, perhatian dan minat, serta perhatian siswa sehingga proses belajar terjadi (Shofwan, 2009), oleh karena itu guru dituntut untuk menguasaai teknik pembelajaran berbasis Information and Communication Technology (ICT) hal ini ditegaskan oleh (Arda et al., 2015) dan (Yazdi et al., 2012).

Beberapa Kegiatan tentang penerapan media pembelajaran telah dilakukan oleh (Rahmi et al., 2020) yang membahas tentang penggunaan media sempoa, penggunaan media sempoa juga telah dilakukan oleh (Anugrahana, 2019), sedangkan (Alimudin et al., 2019) membahas tentang media pembelajaran menggunakan Ms.Office Power Point. Hasil dari beberapa kegiatan diatas menunjukkan bahwa pentingnya guru menggunakan media pembelajaran yang menarik dalam penyampaian materi dan mengkombinasikan beberapa metode pembelajaran tidak hanya meggunakan metode ceramah saja.

\section{METODE}

Metode pelaksanaan kegiatan pengabdian ini berupa demonstrasi dan pelatihan, metode pelatiihan merupakan metode yang efektif untuk digunakan dalam penyampaian materi kepada mitra hal ini telah dibuktikan oleh (Sari et al., 2019) pelatihan desain grafis yang dilaksanakan dapat meningkatkan pengetahuan dan keterampilan pemuda rentan. kegiatan pengabdian diawaali dengan melakukan pengamatan langsung (survey lapangan), mengadakan pertemuan dengan melakukan 
wawancara dan diskusi dengan mitra untuk menyampaikan program dan mengajak mitra bersama-sama aktif merealisasikan program penerapan iptek dan program kegiatan pelatihan. Tahapan pelaksanaan sebagai berikut :

1. Tahap Persiapan yakni pembuatan Handout tentang pembuatan media pembelajaran interaktif yang akan digunakan oleh guru sebagai panduan selama pelatihan

2. Tahap Pelaksanaan Kegiatan yakni memandu para guru dalam membuat media pembelajaran interaktif dengan memanfaatkan teknologi informasi, media yang dibuat tidak hanya menyampaikan toeritis namun manyediakan sesi game agar siswa tidak bosan dalam belajar.

3. Tahap evaluasi kegiatan yakni melakukan monitoring kegiatan secara berkala untuk setiap tahapan dan evaluasi hasil belajar siswa setelah menggunakan media pembelajaran interaktif.

\section{HASIL DAN PEMBAHASAN}

Kegiatan pengabdian kepada masyarakat ini dilaksanakan pada tanggal 30 April 2021 di SDIT Al Izzah Kota Dumai yang beralamat di Jl.Kesuma Komp.BTN Panorama Jaya Mukti. Adapun rangkaian kegiatan pengabdian diawali dengan penyampaian kata sambutan dari kepala sekolah Al Izzah dilanjutkan dengan kata sambuatan dari ketua Tim Pengabdian STT Dumai. Kemudian dilanjutkan dengan pemaparan materi yang langsung dipraktekkan oleh guru di laptop masing-masing, hal ini dapat dilihat pada gambar berikut :

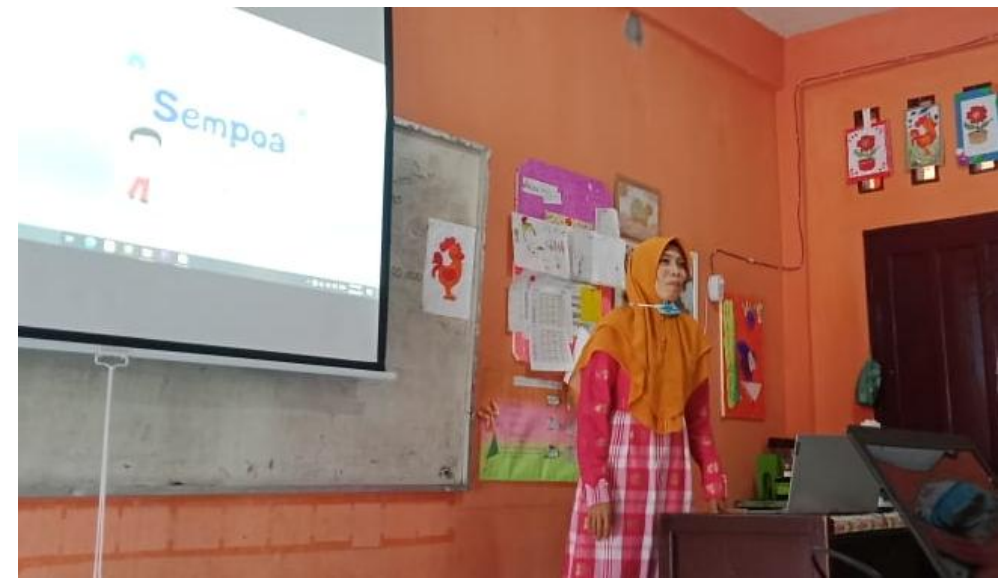

Gambar 2. Pemaparan Materi

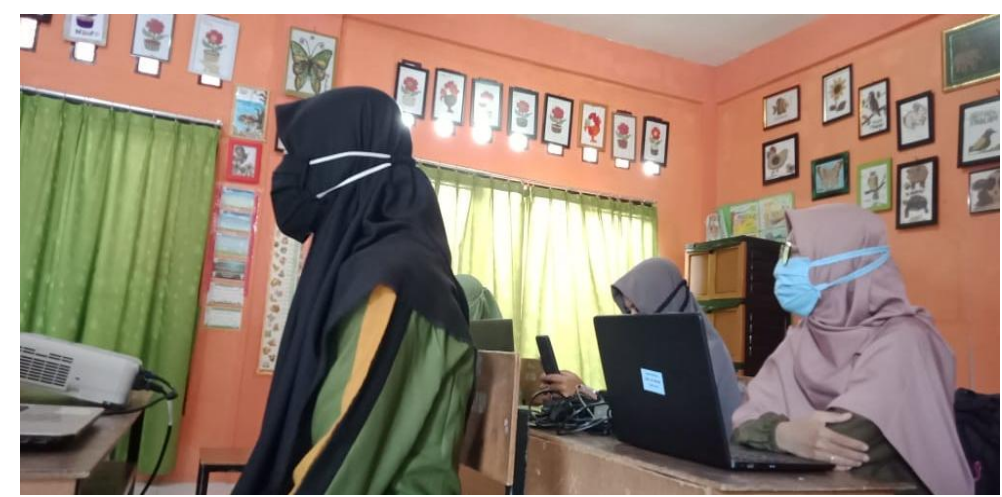

Gambar 3. Antusias Mitra Mengikuti Pelatihan 


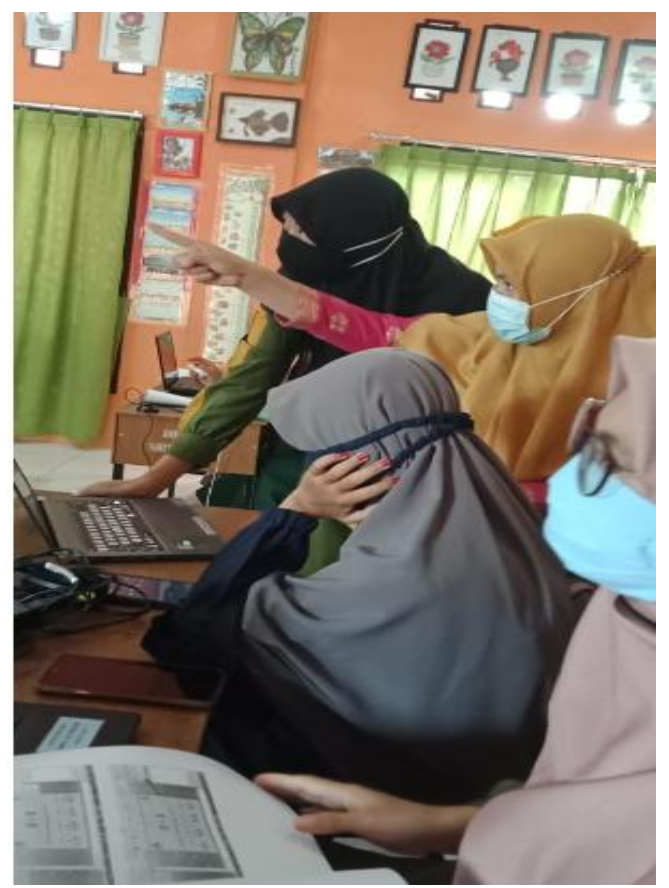

Gambar 4. Sesi Praktek dan Tanya Jawab

Selama praktek pembuatan media pembelajaran sempoa berbasis teknologi informasi guru juga dibekali dengan Modul untuk dapat digunakan selama pelatihan dan disaat kelak ada langkah yang lupa dalam pembuatan media ini. Guru didampingi hingga berhasil membuat media pembelajaran. Gambar 5 merupakan hasil atau karya guru membuat media pembelajaran.

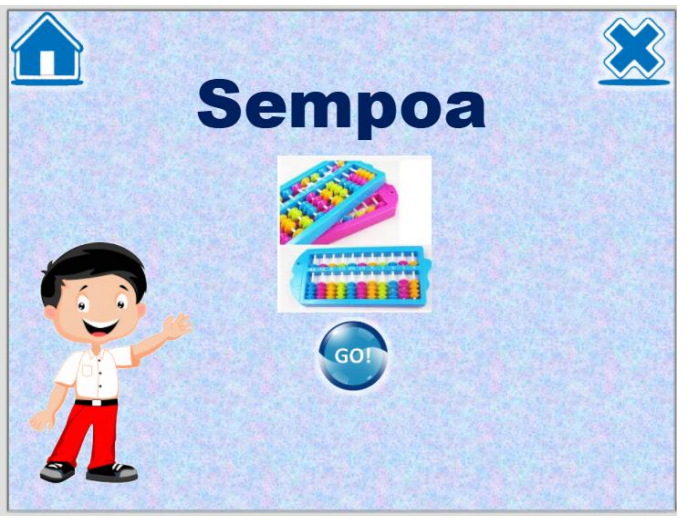

Gambar 5 (a). Tampilan Awal

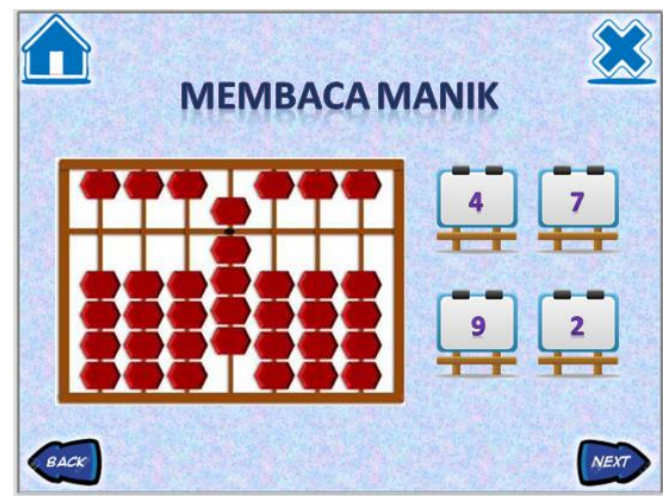

Gambar 5 (c). Quis

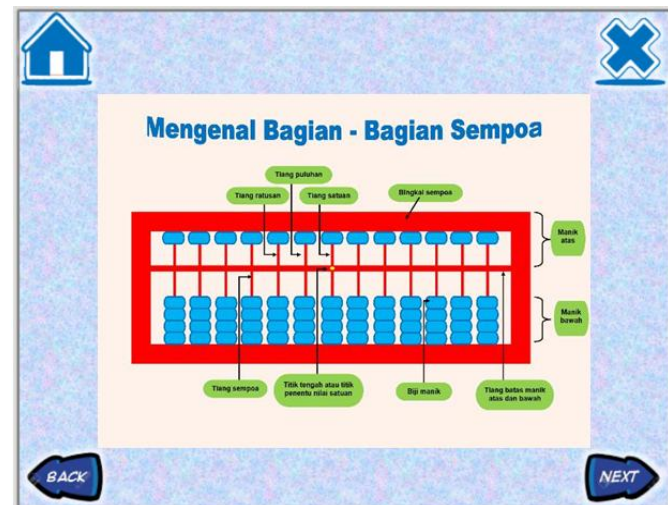

Gambar 5 (b). Pendahuluan

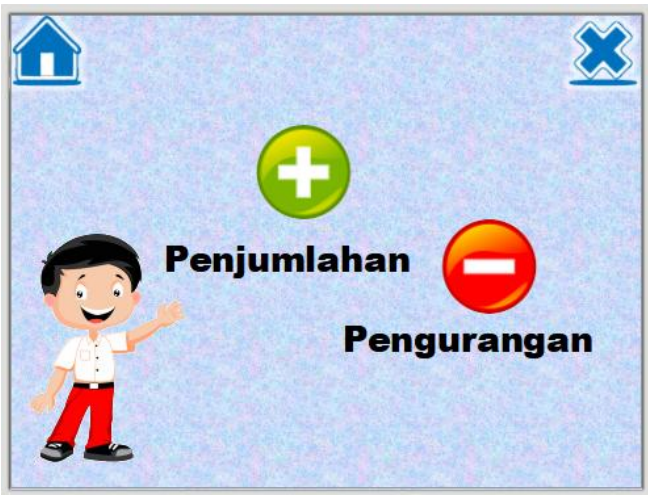

Gambar 5 (d). Materi 
Sebagai bahan evaluasi untuk melihat peningkatan kemampuan siswa diberikan latihan dapat dilihatpada gambar 6 berikut ini:

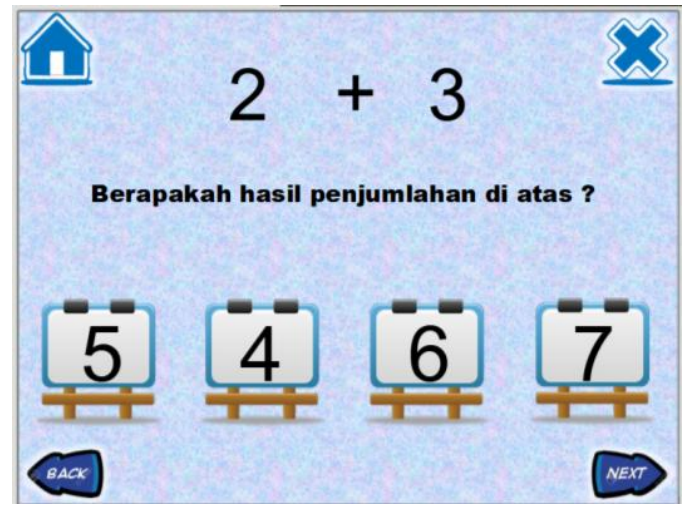

Gambar 6 (a). Bentuk Soal Latihan

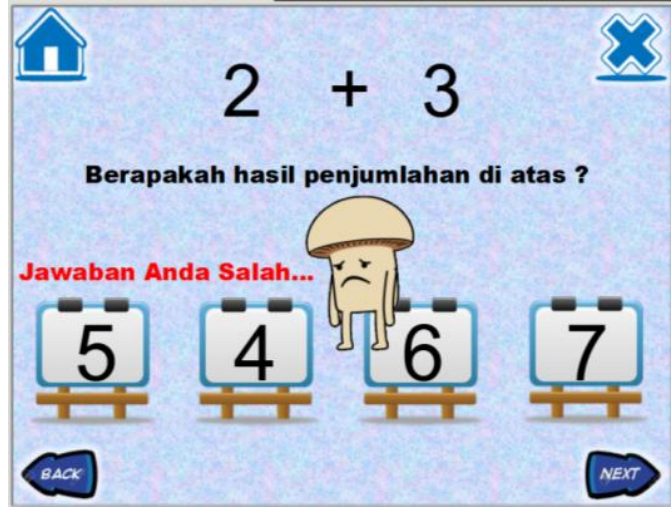

Gambar 6 (b). Animasi ketika jawaban salah

Kegiatan diakhiri dengan penutupan dan doa bersama. Program pengabdian masyarakat ini telah selesai dilaksanakan, namun tim tetap melakukan pendampingan hingga dilaksanakannya evaluasi terhadap hasil belajar siswa,

\section{KESIMPULAN}

Program pengabdaian kepada masyarakat yang telah dilaksanakan memberikan dampak yang positif yakni Guru memiliki kemampuan membuat dan menggunakan media pembelajaran interaktif berbasis teknologi informasi khususnya pada pelajaran matematika. Berdasarkan hasil evaluasi yang diadakan setelah guru menggunakan media pembelajara interaktif ini kemampuan siswa baik dari segi kecepatan dan ketepatan menjawab mengalami peningkatan yang dibuktikan dengan meningkatnya nilai rata-rata kelas pada mata pelajaran metematika dan tidak ada siswa yang nilai matematikanya dibawah KKM.

\section{UCAPAN TERIMA KASIH}

Terimakasih tim pengabdian ucapkan kepada Yayasan Lembaga Pendidikan Islam (YLPI), Sekolah Tinggi Teknologi Dumai yang telah mendanai kegiatan pengabdian ini sehingga terlaksana dengan baik. Tak lupa Tim juga mengucapkan terimakasih kepada LPPM STT Dumai yang telah menjadi fasilitator terlaksananya program pengabdian ini. Selanjutnya ucapan terimakasih Kepala Sekolah SDIT Al Izzah dan segenap Guru Kelas 1 yang telah bersedia menjadi mitra dan sangat antusias dalam mengikuti kegiatan pelatihan hingga selesai.

\section{DAFTAR PUSTAKA}

Alimudin, E., Yuliati, T., \& Nugraha, N. B. (2019). Pelatihan Media Pembelajaran Dengan Ms . Office Power Point Bagi Guru SMA IT Plus Bazma Brilliant Dumai. Madani : Indonesia Journal Of Civil Society, 1(1), 11-16.

Anugrahana, A. (2019). Pengembangan Modul Sempoa Sebagai Alternatif. Jurnal Cendikia : Jurnal Pendidikan Matematika, 03(02), 462-470.

Arda, Saehana, S., \& Darsikin. (2015). Pengembangan Media Pembelajaran Interaktif Berbasis Komputer Untuk Siswa SMP Kelas VIII. E-Jurnal Mitra Sains, 3(1), 6977.

Ayuningtyas, A., Setiawan H, A., Pujiastuti, A., Retnowati, N. D., \& Indrianingsih, Y. 
(2018). Pendampingan Pembuatan Bahan Ajar Bagi Guru Sekolah Dasar Islam Terpadu ( SDIT ) Salsabila Al Muthi ' in Berbasis Multimedia dengan Menggunakan Microsoft Power Point. Jurnal Pengabdian Masyarakat Bidang Teknologi, Kacanegara, 1(1), 1-6.

Dianto, R., Setiowati, D., Mukaromah, L., Tarbiyah, F., \& Bengkulu, I. (2018). Penggunaan Sempoa Untuk Meningkatkan Mental Aritmetika Siswa SD pada Pembelajaran Kabataku. Jurnal Equation, 1(2), 145-152.

Rahmi, H., Saputra, J., \& Desriati, W. (2020). Peningkatan Kemampuan Berhitung Siswa Kelas II Dengan Menggunakan Sempoa Aritmatika. Madani : Indonesia Journal Of Civil Society, 2(2), 50-56. https://doi.org/10.35970/madani.v1i1.148

Rustyaning, H. L., \& Arthana, I. K. P. (2016). Pengembangan Media Komputer Pembelajaran ( CAI ) Pada Mata Pelajaran Fisika Materi Pokok Kalor Kelas VII-A. Jurnal Teknologi Pendidikan, 4(1), 33-38.

Sari, F., Handayani, T., \& Mahmud, S. F. (2019). Peran Pelatihan Desain Grafis dalam Mewujudkan Pemuda Rentan yang Memiliki Keterampilan dan Kemandirian. Unri Conference Series: Community Engagement, 1, 493-498. https://doi.org/10.31258/unricsce.1.493-498

Shofwan, A. (2009). Pengembangan Media Pembelajaran Interaktif Mata Kuliah Medan Elektromagnetik. Jurnal Edukasi \& Elektro, 5(1), 11-18.

Yazdi, M., Matematika, D. J., \& Tadulako, U. (2012). E-Learning Sebagai Media Pembelajaran. Jurnal Ilmiah Foristek, 2(1), 143-152. 